\title{
Вплив реабілітаційної програми на фізичну активність хворих ожирінням
}

\author{
Аравіцька М. Г. \\ ДВНЗ «Прикарпатський національний університет імені Василя Стефаника», \\ м. Івано-Франківськ, Україна
}

Актуальність. Ожиріння - одне з найпоширеніших хронічних неінфекційних захворювань. Основою його корекції є довготривала зміна стилю життя за рахунок збільшення фізичної активності на тлі модифікації харчування.

Мета дослідження: визначення динаміки фізичної активності хворих на ожиріння під впливом реабілітації.

Матеріали та методи. Проведено опитування 124 осіб другого зрілого віку $з$ аліментарно-конституційним ожирінням (56I ступеня, 41 - II ступеня, 27 - III ступеня, встановленим за індексом маси тіла) та 63 осіб без ознак ожиріння. Для оцінки рівня фізичної активності застосовували International Physical Activity Questionnaire (IPAQ) у скороченому варіанті. Тестування хворих ожирінням проводили до та після впровадження річної індивідуально-орієнтованої комплексної програми реабілітації, що включала збільшення фізичної активності, зміну стилю харчування, рефлексотерапію, масаж, покращення психоемоційного стану, вироблення свідомого активного ставлення до процесу схуднення.

\section{Результати дослідження та їх обгово-} рення. Для хворих на ожиріння I-III ступеня важкості притаманний вірогідно нижчий рiвень фізичної активності, прямо пропорцій- ний ступеню ожиріння, порівняно з особами 3 нормальною масою тіла. Відповідно найбільший ступінь гіподинамії виявлявся у хворих ожирінням III ступеня. Річне впровадження індивідуально-орієнтованої комплексної програми реабілітації дозволило досягнути статистично значущого $(\mathrm{p}<0,05)$ покращення відносно вихідних показників усіх досліджуваних параметрів фізичної активності (інтенсивної, помірної, ходи пішки) осіб з ожирінням. Хворі ожирінням I ступеня досягли рівня фізичної активності осіб з нормальною масою тіла $(\mathrm{p}<0,05)$. Найбільший приріст тижневих енерговитрат виявили хворі ожирінням III ступеня, переважно за рахунок виконання інтенсивної фізичної активності.

Висновки. Внаслідок впровадження розробленої комплексної реабілітаційної програми визначено статистично значуще збільшення всіх видів фізичної активності хворих ожирінням I-III ступеня порівняно 3 вихідним результатом.

Перспективи подальших досліджень полягають у поглибленому дослідженні впливу засобів реабілітації на стан організму хворих ожирінням.

Ключові слова: реабілітація, ожиріння, фізична активність.

Конфлікт інтересів. Автор заявляе, що не існує ніякого конфлікту інтересів. 